\title{
Patogenia de las Infecciones Virales I
}

\author{
(Pathogeny of viral infections I)
}

Ximena Collao, Nicolás Faúndes

Laboratorio de Virología, Escuela de Medicina, Universidad de Valparaíso.

*Autor para correspondencia: ximena.collao@uv.cl

RECIBIDO: 26 de Febrero de 2019

APROBADO: 05 de Marzo de 2019

DOI: 10.22370/bolmicol.2019.34.1.1581

LOS AUTORES DECLARAN NO TENER CONFLICTO DE INTERESES

Palabras claves: Virus; Patogenia.

Key words: Virus; Pathogeny.

\section{INTRODUCCION}

La patogenia comprende una serie de eventos y procesos que se combinan para producir enfermedad. La patología está relacionada con las anormalidades resultantes de la reacción a la injuria. La relación virus-célula producida durante la infección viral en un huésped no corresponde necesariamente a la observada en el tejido ya que existen factores que determinan que un virus pueda o no infectar un huésped y que dicha infección se manifieste o no en enfermedad.

El resultado de una infección viral depende tanto del virus como del hospedador, relación que se manifiesta a nivel de la célula, del organismo y de la población de hospedadores. En este último nivel la infección puede manifestarse como enfermedad epidémica, endémica o esporádica.

A nivel del organismo, la interacción de los factores mencionados determinará el destino final de la infección. Esta puede ser:

- No hay infección

- Infección aguda
- Infección persistente clasificada como latente, crónica o lenta

- Infección transformante que origina tumor benigno o maligno

\section{PATOGENIA}

\section{Patogenia a nivel celular}

Hay que considerar:

1) Factor viral.

2) Respuesta celular o consecuencia celular de la infección.

3) Susceptibilidad celular.

\subsection{Factor Viral}

El virus puede ser virulento o atenuado respecto a su célula huésped. Vamos a considerar el concepto de virulento sinónimo de patógeno y denominaremos atenuado a un virus carente total o parcialmente de poder patógeno.

Un virus puede ser virulento para una célula del organismo y atenuado para otra, vale decir, la virulencia del virus suele ser altamente específi- 
ca para ciertos linajes celulares o restringidos para células en órganos y tejidos que tienen un origen embriológico común.

Pueden existir virus cuyas cepas son virulentas para cierto tipo de células pero que espontáneamente o artificialmente generan otras cepas atenuadas para estas mismas células. (Virus vacunales: sarampión, polio, etc.).

\subsection{Consecuencia celular de la infección}

La replicación viral en la Célula hospedadora puede dar como resultado:

- La destrucción de la célula (efecto citocídico) con replicación productiva (hay progenie viral).

- Infección persistente con o sin ninguna alteración celular. Puede o no haber progenie viral.

- Transformación de la célula (se da en los virus oncogénicos) no citocida.

\subsubsection{Destrucción celular o infección citocídica}

La mayoría de los virus patógenos para el hombre son virus productivos y potencialmente citocídicos, es decir que la replicación viral en la célula provoca alteración en la biosíntesis celular, conduciendo rápidamente a la destrucción celular, llegando a la muerte rápidamente. Lo que puede ocurrir por lisis celular (virus citolíticos) o en forma más lenta (los con manto o envoltura, que se liberan por yemación).

La aparición del daño histológico producido en cultivo celular por algunos virus citocidas, conocido como efecto citopatogénico (C.P.E.), es a menudo suficientemente característico para usarse como un criterio diagnóstico (ver anexo).

Los mecanismos generales de daño celular que pueden desarrollarse son:

- Los virus pueden codificar enzimas que inhiben el RNA celular y la síntesis de proteínas. Como consecuencia el DNA del huésped declina también. Tal inhibición de la síntesis trae consigo la muerte de la célula.
- Algunas proteínas del cápside viral en altas dosis son a menudo tóxicas, lo que puede ser la principal causa de muerte de la célula hospedadora Ej.: Pentón del adenovirus que inhibe el RNA y DNA celular y por lo tanto síntesis de proteína.

- También se pueden liberar enzimas lisosomales que conducen a la destrucción de la célula.

\subsubsection{Persistencia}

Como regla, la infección de células permisivas con virus líticos o citocidas lleva a infección productiva y muerte celular como se ha visto anteriormente. Sin embargo, ocasionalmente se observan cultivos de células que mientras se multiplican normalmente, liberan cantidades significativas de virus. Se dice que tales cultivos están infectados en forma persistente.

Básicamente, la gran variedad de interacción virus-célula descrito como infecciones persistentes en cultivos celulares (in vitro) pueden ser clasificados dentro de algunas de estas tres categorías:

- Infección productiva no citocida de estado estacionario: es aquella en la cual las células producen virus pero su metabolismo no es afectado por el virus. Todas las células producen continuamente un virus no citocidal.

- Persistencia del genoma viral: el genoma viral puede integrarse con el de las células en el cultivo o puede persistir en forma circular unido a un punto del cromosoma (episomal). Algunas circunstancias pueden activar el genoma y producirse un ciclo lítico con producción viral. Esta situación se observa in vivo e in vitro con los virus herpes. La capacidad de persistencia con integración al genoma se observa también en los virus transformantes, que se verán a continuación.

\subsubsection{Transformación}

Ciertos virus DNA (papiloma virus) y los Retrovirus (HTLV I y HTLV II) pueden integrar el DNA viral sintetizado durante la replicación en el genoma celular, generando células transformadas. 
La transformación celular corresponde a un fenómeno que ocurre tanto in vivo como in vitro y tras diversos estudios ha permitido obtener información respecto de la etiología de ciertos cánceres. Es notable apreciar que las células transformadas por virus, presentan DNA viral integrado al DNA celular en forma permanente, y también pueden expresar RNA y antígenos virales.

Las células transformadas in vitro tienen las propiedades de las células neoplásicas, estas son:

- Pérdida de la inhibición por contacto

- Crecimiento a una alta densidad de saturación

- Aparición de antígenos para virus y tumores (T y TSTA)

- Formación de $\mathrm{T}$ depende de la infección a un huésped susceptible.

- Aumento de aglutinación por lecitinas

- Alteración de la morfología celular.

\subsection{Susceptibilidad celular}

La susceptibilidad celular tiene que ver con la capacidad que posee un virus de entrar a una célula, lo cual dependerá de:

- Adsorción viral: dependiendo de presencia o ausencia de receptores en la membrana plasmática de células hospedadoras.

- Factores fisiológicos: en ocasiones, células en cultivo son capaces de ser infectadas por virus que no las infectan in vivo esto se debería a la presentación de receptores.

- Edad del hospedador: ciertos virus son capaces de infectar sólo en edades muy tempranas, por ejemplo los virus coxakie in vitro solo se multiplican en ratas lactantes de no más de dos días.

- Factores genéticos: que pueden ser de susceptibilidad o resistencia pudiendo tener carácter dominante o recesivo. Ellos controlarían la síntesis de receptores de la membrana celular.

Mecanismos de propagación a nivel celular Los virus pueden propagarse a nivel celular por diversos mecanismos, lo que de alguna forma tiene que ver con la respuesta inmune, o con evasión de ella, en el individuo. Esta puede ser:

a. Lisis celular y paso al extracelular. Ej: Enterovirus.

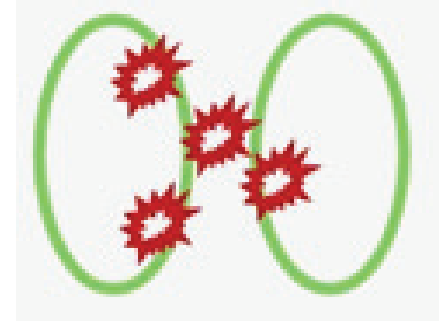

b. Intercelular. Ej.: HSV

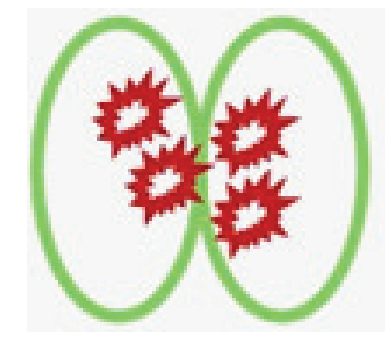

c. Integración al genoma celular. Ej: HPV

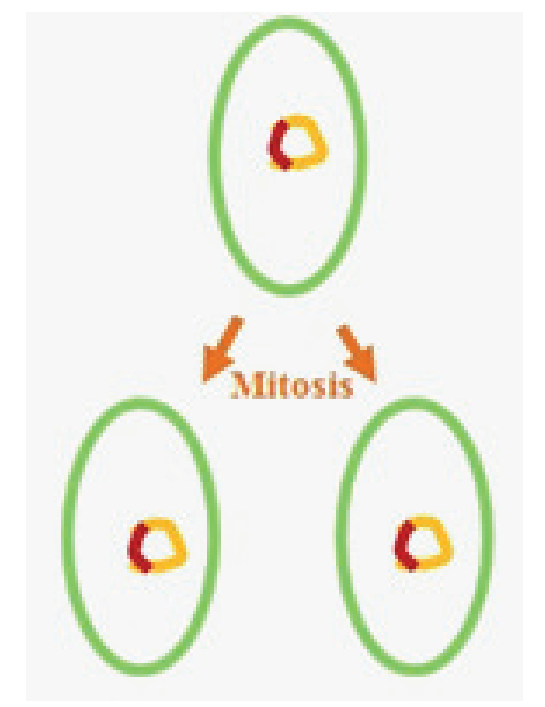

Figura 1. Autora: Dra Ema Navarrete, Adaptada: Nicolás Faúndes 


\section{REFERENCIAS}

Murray, Patrick R., Rosenthal, Ken S., Pfaller, Digard, Paul, A. Nash Anthony, E. Randall RiMichael A. Microbiología Médica, 6ta Edición, chard. Emerging Infectious Disease: Molecular Barcelona España, Elseiver, 2009, Sección 2, Cap: Pathogenesis of Virus infections, Cambridge Uni4, Sección 6, Cap 48. versity, United Kingdom, 2005, Vol 12, N 1

Nafees Ahmad, W. Lawrence Drew, James J. Plorde, Sherris. Microbiología Médica, 5ta Edición, México, Mc Graw Hill, 2010, Parte I, Cap: 1, Parte II, Cap: 6-7. 